\title{
Accounting
}

\section{The effect of cash holdings on firm performance: Evidence from Vietnam listed firms}

\author{
Thu-Trang Thi Doan ${ }^{a^{*}}$
}

${ }^{a}$ Faculty of Finance and Banking, Industrial University of Ho Chi Minh City (IUH), Vietnam

\begin{tabular}{l}
\hline C H R O N I C L E \\
\hline Article history: \\
Received May 102020 \\
Received in revised format May \\
152020 \\
Accepted June 152020 \\
Available online \\
June 152020 \\
\hline Keywords: \\
Cash holdings \\
Firm performance \\
GMM \\
Regression \\
Vietnam \\
\end{tabular}

\section{A B S T R A C T}

The article examines the impacts of cash holding ratio on the performance of firms listed in Vietnam for the period of 2008-2018. The author finds that the proportion of cash holding had a positive impact on the firm performance. The study also shows the impacts of financial leverage, the ratio of tangible assets, firm size, and sales growth on the firm performance. In addition, this is the first study in Vietnam to find a positive and statistically significant impact of state ownership on the firm performance. Thus, the firm performance can be achieved by the effective state capital management. The results of this study provide a reliable basis for financial managers to make appropriate cash holding decisions to improve the firm performance.

\section{Introduction}

Cash is the most liquid asset. The cash holding will help the firms ensure transaction needs, grasp investment opportunities and risk provisions (Keynes, 1936). The cash holding plays an important role for the management of organizations. However, large cash holding will cause the opportunity costs specially when the firm has omitted investment activities that yield a return to choose cash holdings. In addition, the high cash holding also causes agency costs between the firm's managers and shareholders (Jensen, 1986). On the contrary, if the firm does not guarantee its solvency, the firm is in danger of facing financial exhaustion. The cash holding is an issue that has generated a lot of debate in academia and in the financial community. Recently, there have been many studies around the world looking at the relationship between cash holding and firm performance. However, these studies show different results. The study of Rocca and Cambrea (2017) shows a positive relationship between cash holding and firm performance. The high cash holding helps the firms achieve high firm performance (Abushammala \& Sulaiman, 2014). In contrast, the study of Wang (2002) shows the negative impact of cash holding on firm performance. The contradictory debate on the cash holding and the firm performance may stem from the different characteristics of the firms or different institutional contexts.

\footnotetext{
* Corresponding author 
In the context of Vietnam, in recent years, the ratio of cash holding by Vietnamese firms has been increasing, typically for firms such as PV GAS, Petrolimex, Airports Corporation (ACV), Hoa Phat, Vinamilk, Sabeco, Vingroup, Novaland and Vietnam Engine and Agricultural Machinery Corporation - VEAM. These are all leading firms in key sectors of Vietnam's economy. The question is why these firms hold such a large amount of cash. How high cash holding will affect the firm performance. Wang (2002) shows that cash holding affects the interests of investors. In contrast, Abushammala and Sulaiman (2014) show that cash holding benefits the investors. The focus study question of this article will discuss the impact of cash holding on the performance of firms listed on Vietnam's stock market. Although there have been many studies done on this issue. However, these studies are mainly concentrated in developed countries such as England, USA or Europe. The studies in emerging countries like Vietnam are still very limited. The study will help the firms in Vietnam to make appropriate cash holdings to improve their firm performance.

\section{Literature review}

\subsection{Firm performance}

The firms always want to achieve the good performance. There are many financial indicators used to assess the firm performance. To assess the overall firm performance, some studies often use the ratios of return on assets (ROA) and the ratio of return on equity (ROE) (Kangarlouei, et al., 2012). ROA shows the effective use of assets of the firm, which is measured by the ratio of after-tax profits to total assets. On the other hand, ROE shows the effective use of equity of the firm, which is measured by the ratio of after-tax profit to equity of the firm.

\subsection{Cash holdings}

The cash holding is characterized by a collection of cash and highly liquid assets with maturity of less than three months (Gill \& Shah, 2012). Cash holding ratio of the firms is defined as the ratio between cash and cash equivalents to total assets (Vijayakumaran \& Atchyuthan, 2017). Although cash holding is not the goal of the firm, the cash holding helps firms ensure the production activities, impact on investment decisions and thereby affect the firm performance and the value of the firm. Therefore, the cash holding is an issue of interest to researchers. Different theories try to clarify the reasons for cash holding of firms such as the trade-off theory, the order theory and the free cash flow theory. While the trade-off theory and the order theory show a positive relationship of cash holding on firm performance, the free cash flow theory predicts this relationship is negative. The recent empirical studies also provide evidence of a positive relationship of cash holdings to the firm performance (Abushammala \& Sulaiman, 2014; Vijayakumaran \& Atchyuthan, 2017; Rocca \& Cambrea, 2019). For studying Vietnamese firms, the author expects a positive relationship between cash holdings and firm performance. Therefore, the following assumption is made:

\section{H1: Cash holding has a positive impact on the firm performance.}

\subsection{Control variables}

Control variables are necessary to consider that various characteristics of the firm such as financial leverage, the ratio of tangible assets, firm size, sales growth and how the state ownership ratio censors the relationship between the ratio of cash holdings and the firm performance. Financial leverage is used to capture the efficiency of the capital structure of the firm. According to Vijayakumaran and Atchyuthan (2017), leverage is measured by the ratio of liabilities to total assets. The various theories try to explain the impact of leverage on the firm performance. While the trade-off theory predicts the positive impact of leverage on firm performance, the order theory predicts negative impacts. In addition, the empirical studies also try to test the impact of leverage on firm performance. The results of empirical studies also have various results. According to Vijayakumaran and Atchyuthan (2017), the increase in liability use will lead to a decrease in profits, affecting the firm performance. In addition, the recent empirical studies also show a negative relationship between leverage and firm performance (Iftikhar, 2017; Doan, 2020a). In contrast, the studies of Sivathaasan et al. (2013), Seissiana et al. (2018) found positive impacts of leverage on firm performance.The ratio of tangible assets is used to capture the effectiveness of the firm's asset structure. According to Vijayakumaran and Atchyuthan (2017), the ratio of tangible assets is measured by the ratio of tangible fixed assets to total assets. When a firm uses tangible fixed assets effectively, the impact of tangible assets on its firm performance is positive, and vice versa, the negative impact. A number of recent empirical studies, when studying the impact of cash holding on the firm performance all show the negative impact of tangible assets on the firm performance (Vijayakumaran \& Atchyuthan, 2017; Rocca \& Cambrea, 2019). Firm size is measured using the natural logarithm of total assets (Vijayakumaran \& Atchyuthan, 2017). Large-scale firms, with scattered and ineffective projects, will reduce the firm performance (Doan, 2020b). Other studies have found a positive impact of firm size on firm performance. Larger firms use advanced technologies to make the management process more efficient, thereby increasing the firm performance. In addition, sales growth represents growth prospects and investment opportunities of firms. High sales growth shows that the firm has good growth prospects and has many investment opportunities that bring income to the firms, helping increase the firm performance. State ownership ratio is one of the indicators representing the ownership ratio of a firm. The relationship between state ownership and firm performance has been extensively studied, empirical evidence has provided various results. The state ownership ratio has a positive impact on firm performance 
due to support from political connections and government support ( $\mathrm{Yu}, 2013)$. A number of other studies also show the positive impact of state ownership on the firm performance (Jiang et al. (2008); Nhan \& Ha, 2016). In contrast, Qi et al. (2000) found the positive impact of state ownership on the firm performance.

\section{Data and methodology}

\subsection{Data}

The study paper uses data from audited financial statements published on the websites of 186 non-financial firms listed on Vietnam's stock market over the period of 2008-2018. Data only includes firms listed during the study period. After collecting data, the author has performed the calculation of variables in the study model.

\section{Table 1}

How to measure variables

\begin{tabular}{|c|c|}
\hline Name of variable & How to measure variable \\
\hline \multicolumn{2}{|c|}{ Dependent variables } \\
\hline Return on assets (ROA) & After tax profits/total assets \\
\hline Return on equity (ROE) & After tax profits/equity \\
\hline \multicolumn{2}{|c|}{ Independent variables } \\
\hline Ratio of cash holding (CASH) & Cash and cash equivalents/total assets \\
\hline \multicolumn{2}{|c|}{ Control variables } \\
\hline Leverage (LEV) & Total liabilities/total assets \\
\hline The ratio of tangible assets (TANG) & Tangible fixed assets/total assets \\
\hline Firm size (SIZE) & Logarite of total assets \\
\hline Sales growth (GROWTH) & (Sales in year $\mathrm{t}-$ Sales in year $\mathrm{t}-1)$ / Sales in year $\mathrm{t}-1$ \\
\hline State ownership ratio (SO) & Common shares owned by the State/outstanding shares \\
\hline
\end{tabular}

\subsection{Methodology}

Based on the results of previous studies, the author sets up a quantitative study model to find out the impact of cash holding ratio on performance of firms in Vietnam. The expected equation is as follows:

$$
\begin{aligned}
& R O A_{i t}=\beta_{0}+\beta_{I} C_{A S H_{i t}+\beta_{2} L E V_{i t}+\beta_{3} T A N G_{i t}+\beta_{4} S I Z E_{i t}+\beta_{5} G R O W T H_{i t}+\beta_{6} S O_{i t}+\varepsilon_{i t}} \\
& R O E_{i t}=\beta_{0}+\beta_{I} C A S H_{i t}+\beta_{2} L E V_{i t}+\beta_{3} T A N G_{i t}+\beta_{4} S I Z E_{i t}+\beta_{5} G R O W T H_{i t}+\beta_{6} S O_{i t}+\varepsilon_{i t}
\end{aligned}
$$

where

Dependent variables: Return on assets of firm $i$ in year $t\left(R O A_{\mathrm{it}}\right)$, Return on equity of firm $i$ year $t\left(\mathrm{ROE}_{\mathrm{it}}\right)$.

Independent variable: Cash holding ratio of firm $i$ in year $t\left(\mathrm{CASH}_{\mathrm{it}}\right)$

Control variable: Financial leverage of firm $i$ in year $t\left(\mathrm{LEV}_{\mathrm{it}}\right)$, ratio of tangible fixed assets of firm i in year t $\left(\mathrm{TANG}_{\mathrm{it}}\right)$, size of firm $i$ in year $t\left(\mathrm{SIZE}_{\mathrm{it}}\right)$, sales growth of firm $i$ in year $t\left(\mathrm{GROWTH}_{\mathrm{it}}\right)$, the state ownership ratio of firm $i$ in year $t\left(\mathrm{SO}_{\mathrm{it}}\right)$.

The author uses the methods of Pooled regression (POLS), Fixed effects model (FEM) and Random effects model (REM). Through testing $F$ and Hausman, the author chooses the best of the three methods. The author has then performed tests of multicollinearity, heteroscedasticity (Modified Wald test), and autocorrelation (Wooldridge test). Finally, the author analyzes the model according to the Generalized Method of Moment (GMM). The GMM method has great advantages in overcoming the regression hypotheses that are violated and ensures the results are firm and effective (Doytch \& Uctum, 2011; Bui, 2020; Doan \& Bui, 2020).

\section{Empirical Results}

Data of 186 non-financial firms listed on Vietnam's stock market in the 2008-2018 period are shown with the following variables in Table 2

\section{Table 2}

\begin{tabular}{|c|c|c|c|c|c|}
\hline Variables & Obs. & Median & Std. Dev. & Min & Max \\
\hline ROA & 2046 & 0.0707 & 0.0750 & -0.6455 & 0.7837 \\
\hline ROE & 2046 & 0.1315 & 0.1397 & -2.3209 & 0.9821 \\
\hline CASH & 2046 & 0.1061 & 0.1081 & 0.0002 & 0.9437 \\
\hline LEV & 2046 & 0.4750 & 0.2207 & 0.0199 & 0.9513 \\
\hline TANG & 2046 & 0.2030 & 0.1870 & 0.0000 & 0.9776 \\
\hline SIZE & 2046 & 11.7291 & 0.6520 & 9.8319 & 13.9513 \\
\hline GROWTH & 2046 & 1.2168 & 0.8476 & 0.2352 & 14.0220 \\
\hline SO & 2046 & 0.0028 & 0.0022 & 0.0000 & 0.0082 \\
\hline
\end{tabular}

Descriptive statistics of variables

Source: Computed by the Author.

The correlation coefficients between the variables are described in Table 3 below: 
Table 3

Correlation coefficients between variables

\begin{tabular}{cccccccc}
\hline & ROA & ROE & CASH & LEV & TANG & SIZE & GROWTH \\
\hline ROA & 1.0000 & & & & & \\
ROE & 0.8008 & 1.0000 & & & & & \\
CASH & 0.3180 & 0.2048 & 1.0000 & & & & \\
LEV & -0.4235 & -0.0558 & -0.2810 & 1.0000 & & & \\
TANG & -0.0195 & -0.0395 & -0.1272 & -0.0089 & 1.0000 & & \\
SIZE & 0.0407 & 0.1449 & 0.0127 & 0.3007 & 0.0449 & 1.0000 & 1.0000 \\
GROWTH & 0.4769 & 0.3571 & 0.1413 & -0.1532 & -0.0050 & 0.0477 & 0.0923 \\
SO & 0.1154 & 0.1337 & 0.0413 & 0.0983 & 0.2537 & 0.0782 & 1.0000 \\
\hline
\end{tabular}

Source: Computed by the Author.

Correlation analysis shows that CASH variables positively correlated with ROA and ROE. The control variables SIZE, GROWTH and SO are positively correlated with ROA and ROE. In contrast to the control variables LEV, TANG are negatively correlated with ROA and ROE.

\section{Table 4}

Model results using POLS, FEM, REM methods (Model 1)

\begin{tabular}{|c|c|c|c|}
\hline $\mathrm{ROA}$ & POLS & FEM & REM \\
\hline Constant & $-0.0979^{* * *}$ & $-0.3044^{* * *}$ & $-0.1460^{* * *}$ \\
\hline CASH & $0.1032^{* * *}$ & $0.0792^{* * *}$ & $0.0918^{* * *}$ \\
\hline LEV & $-0.1264^{* * *}$ & $-0.1238^{* * *}$ & $-0.1301^{* * *}$ \\
\hline TANG & $-0.0142^{* *}$ & $-0.0462^{* * *}$ & $-0.0256^{* * *}$ \\
\hline SIZE & $0.0144^{* * *}$ & $0.0333^{* * *}$ & $0.0195^{* * *}$ \\
\hline GROWTH & $0.0338^{* * *}$ & $0.0249^{* * *}$ & $0.0277^{* * *}$ \\
\hline $\mathrm{SO}$ & $3.5934^{* * *}$ & $4.6999^{* * *}$ & $3.9316^{* * *}$ \\
\hline $\mathrm{R}^{2}$ & $40.58 \%$ & $54.38 \%$ & $63.33 \%$ \\
\hline $\begin{array}{l}\text { Significance level } \\
\text { F test } \\
\text { Hausman test }\end{array}$ & $\begin{array}{l}F(6,2039)=232.04 \\
\text { Prob }>F=0.0000^{* * *}\end{array}$ & $\begin{array}{c}\mathrm{F}(6,1854)=72.60 \\
\text { Prob }>\mathrm{F}=0.0000^{* * *} \\
\mathrm{~F}(185,1854)=4.33 \text { Prob }>\mathrm{F}=0.0000^{* *} \\
\text { chi2 }(6)=82.70 \text { Prob }>\text { chi } 2=0.0000^{* * *}\end{array}$ & $\begin{array}{l}\text { Wald chi2 }(6)=779.27 \\
\text { Prob }>\text { chi } 2=0.0000^{* * *}\end{array}$ \\
\hline
\end{tabular}

Source: Computed by the Author.

Note: ${ }^{* *}$ and ${ }^{* * *}$ indicate significance at the $5 \%$ and $1 \%$ level, respectively.

The author uses regression methods on table data, including: Pooled Regression (POLS), Fixed effects model (FEM) and Random effects model $(\mathrm{REM})$. Model $(1)$ with $\mathrm{F}$ test $(185,1854)=4.33$ is statistically significant at the $1 \%$ significance level, Hausman test chi2 $(6)=82.70$ is statistically significant at the $1 \%$ significance level. Thus, the study results of the model (1) show that the Fixed effects model (FEM) regression method proved to be suitable. The author will conduct study model test based on the results of FEM model.

\section{Table 5}

Results of VIF, heteroscedasticity and autocorrelation tests (Model 1)

\begin{tabular}{lcccccc}
\hline Variable & CASH & LEV & TANG & SIZE & GROWTH & SO \\
VIF & 1.14 & 1.26 & 1.10 & 1.13 & 1.05 & 1.1 \\
\hline
\end{tabular}

Modified Wald test chi2 $(186)=10^{5}$ Prob $>$ chi2 $=0.0000^{* * *} \quad$ Wooldridge test $\mathrm{F}(1,185)=18.036$ Prob $>\mathrm{F}=0.0000^{* * *}$

Source: Computed by the Author.

Note: ${ }^{* * *}$ indicates significance at the $1 \%$ level.

The multi-collinearity of Model 1 is considered not to be serious. However, the study model has heteroscedasticity and the autocorrelation. To overcome the heteroscedasticity and the autocorrelation, this artile will use the GMM method for analysis.

Table 6

Model results using POLS, FEM, REM methods (Model 2)

\begin{tabular}{cccc}
\hline \multicolumn{1}{c}{ POA } & POLS & FEM & REM \\
\hline Constant & $-0.2760^{* * *}$ & $-0.5590^{* * *}$ & $-0.3275^{* * *}$ \\
CASH & $0.1847^{* * *}$ & $0.1570^{* * *}$ & $0.1722^{* * *}$ \\
LEV & -0.0097 & -0.0364 & -0.0231 \\
TANG & $-0.0386^{* *}$ & $-0.0904^{* * *}$ & $-0.0558^{* * *}$ \\
SIZE & $0.0271^{* * *}$ & $0.0536^{* * *}$ & $0.0328^{* * *}$ \\
GROWTH & $0.0525^{* * *}$ & $0.0438^{* * *}$ & $0.0468^{* * *}$ \\
SO & $6.2905^{* * *}$ & $9.5262^{* * *}$ & $7.1355^{* * *}$ \\
\hline$R^{2}$ & $17.82 \%$ & $31.37 \%$ & $36.41 \% \%^{* * *}$ \\
Significance level & $\mathrm{F}(6,2039)=73.67$ & $\mathrm{~F}(6,1854)=33.62$ & Wald chi2(6) $=304.10$ \\
F test & & $\mathrm{F}(185,1854)=3.05$ & \\
Hausman test & & chi2 $(6)=19.49$ & \\
\hline
\end{tabular}

Source: Computed by the Author.

Note: ${ }^{* *}$ and ${ }^{* * *}$ indicate significance at the $5 \%$ and $1 \%$ level, respectively. 
Model (2) with F test $(185,1854)=3.05$ is statistically significant at the $1 \%$ significance level, Hausman test Chi2 $(6)=19.49$ is statistically significant at the $1 \%$ significance level. Thus, the study results of the model (2) show that the Fixed effects model (FEM) regression method proved suitable. The author will conduct study model test based on the results of FEM model.

Table 7

Results of VIF, heteroscedasticity and autocorrelation tests (Model 2)

\begin{tabular}{|c|c|c|c|}
\hline \multicolumn{2}{|c|}{ Multicollinearity test } & \multirow{2}{*}{ Modified Wald test } & \multirow{2}{*}{ Wooldridge test } \\
\hline Variable & VIF & & \\
\hline $\mathrm{CASH}$ & 1.14 & \multirow{7}{*}{$\begin{array}{l}\text { chi2 }(186)=62152.33 \\
\text { Prob }>\text { chi } 2=0.0000^{* * *}\end{array}$} & \multirow{7}{*}{$\begin{array}{c}F(1,185)=9.404 \\
\text { Prob }>F=0.0025^{* * *}\end{array}$} \\
\hline LEV & 1.26 & & \\
\hline TANG & 1.10 & & \\
\hline SIZE & 1.13 & & \\
\hline GROWTH & 1.05 & & \\
\hline $\mathrm{SO}$ & 1.11 & & \\
\hline \multicolumn{2}{|c|}{ Mean VIF $=1.13$} & & \\
\hline
\end{tabular}

Source: Computed by the Author.

Note: ${ }^{* * *}$ indicates significance at the $1 \%$ level.

For Model (2), the multi-collinearity is serious. However, the study model has the heteroscedasticity and the autocorrelation. To overcome the heteroscedasticity and the autocorrelation, this article will use the GMM method for analysis.

Table 8

Model results by GMM method

\begin{tabular}{|c|c|c|c|c|}
\hline & \multicolumn{2}{|c|}{$\begin{array}{c}\text { ROA } \\
\text { (Model 1) }\end{array}$} & \multicolumn{2}{|c|}{$\begin{array}{c}\text { ROE } \\
\text { (Model 2) }\end{array}$} \\
\hline & Coef. & $\mathrm{P}>|\mathrm{z}|$ & Coef. & $\mathrm{P}>|\mathrm{z}|$ \\
\hline Constant & $-0.1673^{* * *}$ & 0.000 & $-0.4635^{* * *}$ & 0.000 \\
\hline CASH & $0.1060^{* * *}$ & 0.000 & $0.1389^{*}$ & 0.051 \\
\hline LEV & $-0.1164^{* * *}$ & 0.000 & $-0.0710^{* * *}$ & 0.002 \\
\hline TANG & $-0.0133^{*}$ & 0.073 & $-0.0421^{* *}$ & 0.029 \\
\hline SIZE & $0.0190^{* * *}$ & 0.000 & $0.0447^{* * *}$ & 0.000 \\
\hline GROWTH & $0.0413^{* * *}$ & 0.000 & $0.0547^{* * *}$ & 0.000 \\
\hline SO & $1.5080^{* * *}$ & 0.005 & $3.5392^{* *}$ & 0.027 \\
\hline \multirow[b]{2}{*}{ Significance level } & \multirow{2}{*}{\multicolumn{2}{|c|}{ Wald chi2 $(5)=1172.14$}} & \multicolumn{2}{|c|}{ Wald chi2 $(5)=337.80$} \\
\hline & & & \multicolumn{2}{|c|}{ Prob $>\operatorname{chi} 2=0.000^{* * *}$} \\
\hline Number of instruments & \multicolumn{2}{|c|}{14} & \multicolumn{2}{|c|}{10} \\
\hline Number of groups & \multicolumn{2}{|c|}{186} & \multicolumn{2}{|c|}{186} \\
\hline Arellano-Bond test for $\operatorname{AR}(2)$ in first & \multicolumn{2}{|c|}{$\mathrm{z}=-1.59$} & \multicolumn{2}{|c|}{$z=-0.60$} \\
\hline differences & \multirow{2}{*}{\multicolumn{2}{|c|}{$\begin{array}{l}\operatorname{Pr}>z=0.111 \\
\operatorname{chi} 2(7)=11.68\end{array}$}} & \multirow{2}{*}{\multicolumn{2}{|c|}{$\begin{array}{l}\operatorname{Pr}>z=0.551 \\
\operatorname{chi} 2(3)=1.47\end{array}$}} \\
\hline Sargan test & & & & \\
\hline Sargan test & \multicolumn{2}{|c|}{ Prob $>$ chi $2=0.112$} & \multicolumn{2}{|c|}{ Prob $>$ chi $2=0.688$} \\
\hline
\end{tabular}

Source: Computed by the Author.

Note: $* * *$ and $* * *$ indicate significance at the $10 \%, 5 \%$ and $1 \%$ level, respectively.

The Sargan test results show that the instruments included in both models are valid. In addition, the Arellano-Bond test shows that the two models are quite good since there is no autocorrelation. Therefore, the study model is suitable and usable. Model results (1) show that ROA is positively impacted by CASH (0.1060), SIZE (0.0190), GROWTH (0.0413), SO (1.5080) with 1\% significance level. ROA is also negatively affected by LEV (-0.1164) with $1 \%$ significance level and TANG (-0.0133) with $10 \%$ significance level. Besides, model results (2) show that ROE is positively affected by CASH (0.1389) with significance level of $1 \%$, SIZE (0.0447), GROWTH (0.0547) with significance level of 10\% and SO ( 3,5392) with a 5\% significance level. In contrast, LEV and TANG are negatively impacted ROE at significance levels of 1\% and 5\%, respectively. The results of the regression analysis have found a positive and statistically significant impact of the cash holding ratio on the firm performance. This means that the firm performance increases in those firms with high cash holding. Thereby, it also explains the status of cash holding ratio of large and leading firms in Vietnam. This result supports the trade-off theory and order theory in explaining the impact of cash holding on firm performance. Similar results were discovered by the studies of Abushammala and Sulaiman (2014), Vijayakumaran and Atchyuthan (2017), Rocca and Cambrea (2019). In addition, the study has also found statistically significant impacts of firm-specific variables acting as a control variable in the study model. Firm-specific variables include: financial leverage (LEV), the ratio of tangible assets (TANG), firm size (SIZE), sales growth (GROWTH) and state ownership (SO). In which financial leverage variables and the ratio of tangible assets have a negative impact on the firm performance, firm size, sales growth and the state ownership have positive impacts on firm performance. This result is entirely consistent with the reality of firms in Vietnam in the study period.

\section{Conclusions}

The empirical study examines the impact of the ratio of cash holding on the performance of listed firms in Vietnam in the period of 2008-2018. The author uses basic methods on table data such as Pooled Regression (POLS), Fixed effects model (FEM), 
Random effects model (REM). The results of the Modified Wald test and the Wooldridge test show that both models suffer from heteroscedasticity and autocorrelation. Therefore, the author has used the GMM method to differentiate the model assumptions and ensure that the estimation is firm and effective. The results have shown the positive impact of the cash holding on firm performance. In addition, the study has also found the impact of financial leverage, the proportion of tangible asset, firm size, sales growth and state ownership ratio on firm performance. The study results are the basis for explaining the reason why Vietnamese firms tend to get high cash holding. The study also contributes to expanding the empirical literature on the impact of cash holding on firm performance in the context of emerging economies in general and Vietnam in particular. However, this study is limited because the data only stops in the period after the global economic crisis in 2008 , therefore, the study has not considered the impact of the economic crisis on the impact on cash holding on the performance of Vietnamese firms. This is also the direction of study for subsequent studies.

\section{References}

Abushammala, S. N. M., \& Sulaiman, J. (2014). Cash Holdings and Corporate Profitability: Some Evidences form Jordan. International Journal of Innovation and Applied Studies, 8(3), 898-907.

Bui, T. N. (2020). How do financial leverage and supply chain finance influence firm performance? Evidence from construction sector. Uncertain Supply Chain Management, 8(2), 285-290.

Doan, T. T. T. (2020a). Financing decision and firm performance: Evidence from an emerging country. Management Science Letters, $10(4), 849-854$.

Doan, T. T. T. (2020b). Profitability of real estate firms: Evidence using GMM estimation. Management Science Letters, 10(2), 327332.

Doan, T. T. T., \& Bui, T. N. (2020). Nonlinear impact of supply chain finance on the performance of seafood firms: A case study from Vietnam. Uncertain Supply Chain Management, 8(2), 276-272.

Doytch, N., \& Uctum, M. (2011). Does the worldwide shift of FDI from manufacturing to services accelerate economic growth? A GMM estimation study. Journal of International Money and Finance, 30(3), 410-427.

Gill, A, \& Shah, C. (2012). Determinants of Corporate Cash Holdings: Evidence from Canada. International Journal of Economics and Finance, 4(1), 70-79.

Iftikhar, R. M. (2017). Impact of cash holding on firm performance: A case study of non-financial listed firms of KSE. University of Haripur Journal of Management, 2(1), 189-199.

Jensen, M. C. (1986). Agency Costs of Free Cash Flow, Corporate Finance, and Takeovers. The American Economic Review, 76(2), 323-329.

Jiang, B. B., Laurenceson, J., \& Tang, K. K. (2008). Share reform and the performance of China's listed companies. China Economic Review, 19(3), 489-501.

Kangarlouei, S. J., Motavassel, M., Azizi, A., \& Farahani, M. S. (2012). The investigation of the relationship between dividend policies, cash-flow uncertainty, contributed capital mix and investment opportunities: the case of emerging markets (Tehran Stock Exchange). International Journal of Business and Social Science, 3(2), 172-180

Keynes, J. M. (1936). The General Theory of Employment Interestand Money. Harcourt, Brace and Company, New York.

Nhan, D. T. T., Ha, P. (2016). Cash Holding, State Ownership and Firm value: The Case of Vietnam. International Journal of Economics and Financial Issues, 6(S6), 110-114.

Qi, D., Wu, W., \& Zhang, H. (2000). Shareholding structure and corporate performance of partially privatized firms: Evidence from listed Chinese companies. Pacifific-Basin Finance Journal, 8(5), 587-610.

Rocca, M. L., \& Cambrea, D. R. (2019). The effect of cash holdings on firm performance in large Italian companies. J Int Financ Manage Account, 30, 30-59.

Seissian, L. A., Gharios, R. T., \& Awad, A. B. (2018). Structural and market-related factors impacting profitability: A cross sectional study of listed companiesa. Arab Economic and Business Journal, 13, 125-133.

Sivathaasan, N., Tharanika, R., Sinthuja, M., \& Hanitha, V. (2013). Factors determining Profitability: A Study of Selected Manufacturing Companies listed on Colombo Stock Exchange in Sri Lanka. European Journal of Business and Management, 5(27), 99-107.

Vijayakumaran, R., \& Atchyuthan, N. (2017). Cash holdings and corporate performance: Evidence from Sri Lanka. International Journal of Accounting \& Business Finance, 3(1), 1-11.

Wang, Y. J. (2002). Liquidity management, operating performance, and corporate value: evidence from Japan and Taiwan. Journal of Multinational Financial Management, 12, 159-169.

$\mathrm{Yu}$, M. (2013). State ownership and fifirm performance: Empirical evidence from Chinese listed companies. China Journal of Accounting Research, 6, 75-87.

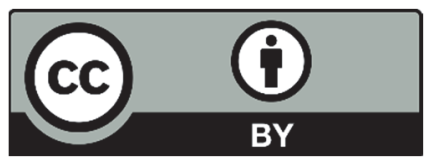

(C) 2020 by the authors; licensee Growing Science, Canada. This is an open access article distributed under the terms and conditions of the Creative Commons Attribution (CC-BY) license (http://creativecommons.org/licenses/by/4.0/). 